\title{
Assessing the performance of Jaggery market in Andhra Pradesh state, India
}

\author{
I.V.Y.Rama Rao, K. Sriram
}

\begin{abstract}
Scientist (Agricultural Economics), Regional Agricultural Research Station, Anakapalle, Visakhapatnam, Andhra Pradesh, India

Assistant Professor (MBA), Dept. of Management Studies, L . Bullayya College, Visakhapatnam, Andhra Pradesh, India
\end{abstract}

\begin{abstract}
Jaggery manufacturing is an important cottage industry in sugarcane growing regions of Andhra Pradesh state, situated in southern part of India. It is worth nearly ₹ 2 billions providing employment to nearly 300 thousand people. The jaggery manufacturers are mostly small and marginal relying on quick returns from jaggery. Present study taken-up with objectives; to calculate the growth of both physical and financial indicators regulated market, to estimate the growth and instability in sugarcane production and to identify the trends in market prices and arrivals of jaggery.

The time series data relating to the monthly arrivals and prices prevailed for the cane jaggery, annual turnover; physical and financial aspects of regulated market was obtained from the annual administrative reports of APMC's (Agricultural Produce Market Committee), Anakapalle, Visakhapatnam, Andhra Pradesh. The area, production and productivity of the sugarcane were collected from Hand book of statistics, compiled and edited by Chief Planning Officer, Visakhapatnam. Andhra Pradesh. Analytical tools like Compound Growth Rate (CGR) and Coefficient of Variation (C.V) were employed to draw the meaningful conclusions from raw data.

Results reveal that Total Turn-Over is more volatile than the total quantity handled. Total Turn-over was more influenced by the price. The physical performance of Agricultural Market Committee (AMC) is good, but coming to financial aspects; it is positive and highly volatile. Positive trend was noticed in prices and arrivals of jaggery in AMC.
\end{abstract}

Keywords- Agricultural Market committee, Anakapalle, Arrivals, Jaggery, Prices.

\section{INTRODUCTION}

Sugar cane is an important commercial crop contributing to 60 per cent of the world's sugar production. During 2012, sugarcane is cultivated in the world with an area, production and yield of 26.10 Million hectares (mha), 1842.3 Million tonnes (mt) and 70.6 Tonnes per hectare (t/ha) respectively (Agricultural Statistics at a glance, 2014). Among the countries Brazil with 9.71 mha of area and $721.08 \mathrm{mt}$ of production leads in the world, but productivity was $74.3 \mathrm{t} / \mathrm{ha}$ only, in which Peru recorded highest with 127.8 t/ha. India ranks second in both area and production, with an area of 5.09 mha $(19.76 \%$ of world's area) and with an average production of 361.04 $\mathrm{mt}(19.71 \%$ in world's production), whereas, yield was $68.8 \mathrm{t} / \mathrm{ha}$.

During 2013-14, among the states, in sugarcane cultivation in India, Utter Pradesh (U.P.) ranks first with an area of 2.22 mha (million hectares) (44.45 per cent share in the total sugarcane area in India) followed by Maharashtra (18.7\%), Karnataka $(8.38 \%)$ and Tamil Nadu $(6.56 \%)$. U.P. ranks first with average production of $135.16 \mathrm{mt}$. In productivity, Tamil Nadu state ranks first with average productivity of $97 \mathrm{t} / \mathrm{ha}$ followed by Karnataka (85.5 t/ha) and Maharashtra (81.7 t/ha) (Indian Sugar, 2014).

Erstwhile Andhra Pradesh (E.A.P.) (as Telangana was separated and formed as new state on 02-06-2014) ranked fifth in area with crop area of 0.19 mha and has a share of 3.83 per cent in the total sugarcane area of the country. The average production of was 15.36 million tonnes contributing to 4.40 per cent of the total production of the country. The average productivity in Andhra Pradesh was $80 \mathrm{t} / \mathrm{ha}$.

In E.A.P, the major sugar cane growing districts in Coastal Andhra, Rayalaseema and Telangana regions are Visakhapatnam (39, 000 ha), Chittore (28, 000 ha) and Nizamabad (19,000 ha) districts respectively. Visakhapatnam district occupies first position in area with 20.3 per cent share in total sugarcane cropped area followed by Chittoor (14.6\%) and Nizamabad (9.9\%). However, the average yield is highest in West Godavari (97.96 t/ha) followed by Nellore $(94.14 / \mathrm{ha})$, Chittoor district (82.54 MT/ha) and Mahaboob Nagar (80.50 t/ha). In India, the three principal sugar products obtained from sugarcane are white sugar, khandasari and jaggery (Gur). The sugar cane utilized in India, for sugar, jaggery and khandsari, seed feed and chewing purpose during the year 1970-71 was 30.2, 57.8 and 12 per cent respectively. During the year 2009-10 it was 66.8, 21.2 and 12 per cent in the same order respectively (Indian Sugar, 2011).

The estimated total jaggery (including khandsari) production in India is 11.79 million tonnes. UP state ranks first with 7.05 million tonnes and 59 per cent share of 
total production, followed by Karnataka (14\% share), Tamil Nadu (11\% share). E.A.P ranks fourth with 0.47 million tonnes of production and 4 per cent share in total production. The average recovery percentage of sugar and jaggery from sugar cane in India is 10 per cent (Cooperative Sugar 2014).

1.1 Jaggery production scenario in Andhra Pradesh

Nerkar (2004) estimated that by 2020 per capita consumption of jaggery and khandasari is going to be 19 $\mathrm{kgs} / A n n u m$. Kumar et al (2010) projected demand for sweeteners for 2015 and 2020 was 32.73 and 36.40 million tonnes respectively.

Jaggery manufacturing is an important cottage industry in sugarcane growing regions of Andhra Pradesh state, situated in southern part of India. It is worth nearly ₹ 2 billions providing employment to nearly 300 thousand people. The jaggery manufacturers are mostly small and marginal relying on quick returns from jaggery. Naidu $\boldsymbol{e t}$ al.(1986) opined that either the supply of sugarcane to the factory or the converted into jaggery mostly depends upon the prevailing prices of jaggery but not on the price of sugarcane. It is believed that a fairly better and stabilized price of jaggery is a threat to the sugar industry. Maheshwarappa et al.,(1998) concluded that net income realized by the raw cane sellers was more because of high price paid by sugar factory ( $₹ 809.08$ per ton) than the price paid for jaggery ( $₹ 592.30$ per quintal).

In E.A.P., Visakhapatnam, Chittoor and Nizamabad districts are the major jaggery producing districts. Anakapalli regulated market located in Visakhapatnam district is the second largest jaggery market in India. Chittoor and Kamareddy regulated markets located in Chittoor and Nizamabad districts are the other two important regulated jaggery markets.

Market performance and policy reforms undertaken by the regulated markets from time to time, needs to be assessed whether it has been keep pace with the developments in production system and the efficiencies of policies for better working of regulated markets to face the challenges of liberalization of trade in the country with following specific objectives.

1. To calculate the growth of both physical and financial indicators regulated market

2. To estimate the growth and instability in sugarcane production

3. To identify the trends in market prices and arrivals of jaggery

\section{MATERIALS AND METHODS}

The present study is mainly concerned with performance of regulated market in Andhra Pradesh in general and Visakhapatnam district in particular. To evaluate the objectives of the study, two stages sampling procedure was adopted. In the first stage, major agricultural commercial commodity i.e., Cane jaggery, in Visakhapatnam district is purposively selected. In the second stage, leading market i.e., Anakapalle Jaggery Market, is selected based on criterion of maximum arrivals in the markets. At the first stage the data was collected for district as a whole and in second stage the data was collected from the Anakapalle regulated market. The time series data relating to the monthly arrivals and prices prevailed for the cane jaggery, annual turnover; physical and financial aspects of regulated market was obtained from the annual administrative reports of APMC's (Agricultural Produce Market Committee), Anakapalle. The area, production and productivity of the sugarcane were collected from Hand book of statistics, compiled and edited by Chief Planning Officer, Visakhapatnam. Andhra Pradesh.

Various statistical and mathematical models were employed to draw the meaningful conclusions from raw data. They are furnished below;

2.1 Analytical Tools:

2.1.1 Estimation of Growth Rates: Compound growth rates (CGR) were estimated by fitting an exponential function of the following form.

$$
\mathrm{Y}=\mathrm{A} \cdot \mathrm{b}^{\mathrm{t}}
$$

Where,

$$
\mathbf{Y}=\text { Dependent Variable like }
$$
area/production/productivity etc $\mathbf{A}=$ Constant

$$
\mathbf{B}=(1+\mathrm{r}) \quad \mathbf{r}=\text { Compound }
$$

Growth Rate $\quad \mathbf{t}=$ Time variable in years $(1,2,3 \ldots \mathrm{n})$

The value of antilog of ' $b$ ' was estimated by using LOGEST function in MS-Excel. Then, the percent Compound Growth Rate is calculated as below;

$$
\text { CGR }(\%)=\left[\operatorname{LOGEST}\left(\mathrm{Y}_{1}: \mathrm{Y}_{10}\right)-1\right] \times 100
$$

2.1.2 Estimation of Variability: Coefficient of Variation $(\mathrm{CV})$ is a popular measure of instability. It is represented by following formulae;

$$
\mathrm{CV}=\frac{\left[1 /{ }_{\mathrm{N}-1} \Sigma\left(\mathrm{X}_{\mathrm{t}}-\overline{\mathrm{X}}\right)^{2}\right]^{1 / 2}}{\mathrm{X}}
$$

Where,

$\mathrm{N}=$ Number of years

$\mathrm{X}_{\mathrm{t}}=$ Area/production/productivity in the year ' $\mathrm{t}$ '

$\overline{\mathrm{X}}=$ Mean of Area/production/productivity.

\section{RESULTS AND DISCUSSIONS}

3.1 Physical performance of regulated market

To assess the Physical performance of Anakapalle Regulated Market, Physical indicators like Total Turnover and Total quantity handled were estimated and presented in Table 1. Perusal of Table 1 reveals that the average Total Turn-over for last decade was ₹ 104.7 crores. The average quantity transacted for last decade was 60, 413.5 Tonnes. But the trend was at declining rate that causes to think twice about reasons. The Compound 
Growth Rate (CGR) for Total Turn-over was $11.53 \%$ indicates that turn-over is increasing at good pace. But, this growth was fully led by price rather than quantity, where, CGR for Total quantity handled was $-0.65 \%$. In otherwords, quantity of arrivals in market is deceasing over a period.

That shows, the Total Turn-over was more influenced by the price. That is a good indicator for farmers. Further, Total turn-over have high fluctuations with $40.5 \%$ Coefficient of Variation (C.V), in compare to $22.49 \%$ of C.V of Total Quantiy Handled. In otherwords, Total Turn-over is deviating from mean Total Turn-over of $\bar{₹}$ 104.7 Crores by $40.50 \%$ and Total Quantity Handled is deviating fom the mean Total Quantity Handled of 60,413.5 Tonnes respectively. It implies that Total TurnOver is more volatile than the total quantity handled.

3.2 Financial performance of regulated market

In order to assess the financial performance of Anakapalle Regulated Market, financial indicators like Income, Expenditure and Net Income were estimated and presented in Table 2.

A look at Table 2, reveals that the income accrued to market committee, being a facilitator for transaction was ₹ 194.3 Lakhs on an average annually. But at the same time expenditure towards facilitator for transaction was $₹ 191.1$ Lakhs on an average annually.

Thus, the net profit annually was ₹ 3.2 lakhs. That shows the market is opearting in profits. Though this profit is growing at positive growth rate of $8.51 \%$ but with highly fluctuating and unpredicable manner with a coefficient of variation of $1025.26 \%$.

The fluctuations in both Expenditure and Income are high, in which expenditure is marginally high with 38.18 $\%$ of Coefficient of Variation than income with C.V of $34.99 \%$. That means expenditure is deviating from mean expenditure of $₹ 191.3$ Lakhs by $38.18 \%$ on both sides i.e., positive and negetive side. Same implies for income also, that is, income fluctuating at $34.99 \%$ from mean price of ₹ 191.1 lakhs.

Thus, from tables 1 and 2 it is concluded that, the physical performane of AMC is good, but coming to financial aspects; it is positive and highly volatile. Main reason attributed by committee officials was dearth of office staff.

3.3 Trends in area, production and productivity of sugar cane in Visakhapatnam district

Annual compound growth rates of area, production and productivity of sugar cane were calculated for the visakhapatnam district of Andhra Pradesh state for the period 1993-94 to 2012-13 and also for each decade termed as sub periods i.e. 1993-94 to 2002-03 as Period I and 2003-04 to 2012-13 as Period - II.

A close perusal of Table 3 reveals that the area showed negetive growth $(-1.85 \%$ and $-0.83 \%)$ in both periods.
That shows that area under sugarcane cultivation is decreasing. Whereas, production and productivity showed positive significant CGR of 2.25, 4.17 and 4.23, 5.10 per cents during sub period - I and period - II respectively. That implies that growth in production was more influenced by growth in productivity.

Coming to the instability aspects in area during Period - I was $25.67 \%$ and $4.06 \%$ during period - II. That shows higher instability in area under sugarcane cultivation. Productivity also showed higher instability $(24.80 \%$ in Period - I and $19.51 \%$ in Period - II). Instability in production was moderate, it was established by way of recording $16.27 \%$ in Period - I and $18.35 \%$ in Period II. In contrast to $\mathrm{CGR}$, in $\mathrm{CV}$, in period - I, production fluctuations was more influenced by area and in period II, production fluctuations was more influenced by productivity.

Rao et al (2011) estimated the growth rates in sugarcane in Visakhapatnam for the periods Pre-WTO (1984-85 to 1994-95) and Post-WTO (2000-01 to 2009-10). They conclude that CGR in Area and production during PreWTO was higher than Post-WTO, whereas, vice versa was noticed in CGR in Productivity.

3.4 Trends in annual arrivals and annual prices of jaggery in the Anakapalle regulated market

The behaviour of arrivals and prices of jaggery in Anakapalle regulated market was studied by analyzing the long term trend and seasonal variations in arrivals and prices and presented through figures 1 to 4 Mean yearly arrivals of jaggery was highest during 2004-05 (70,852 Qtl) and lowest in 2002-03 (32,742 Qtl) with mean monthly arrivals for 2000-01 to 2014-15 was 60413.5 quintals (Fig. 1). Average yearly arrivals of jaggery before 2008-09 was 46,276 quintals. But, average yearly arrivals of jaggery after 2008-09 was 52,069 quintals. Thus, there was a difference of 6,000 quintals between before and after 2008-09.

Fig. 2 reveals tha mean monthly arrivals of jaggery was highest during March (1, 18,673 Qtl) and lowest in July (2553 Qtl) with mean monthly arrivals for 2000-01 to 2014-15 as 48,207 quintals. If we see the difference between peak season arrivals (1,18,673 qtls) and the off season arrivals (2,553 qtls) there was difference of nearly $1,17,000$ quintals. That means seasonal nature of agricultural produce is clearly established.

Mean yearly prices of jaggery was lowest ( ₹ 864) and highest ( ₹ 2,677) during 2000-01 and 2014-15 respectively with mean yearly prices for 2000-01 to 201415 was ₹ 1714 (Fig. 3). Thus, mean yearly prices are fluctuating than the variation in the prices among the months.

Notable changes were occurred during 2007-08 ( ₹ 1019 per quintal) to $2009-10$ ( $₹ 2,633$ per quintal). Prices jumped by 150 percent and then stabilized around the $\vec{R}$ 
2,500 per quintal. Thus, before 2007-08 year prices are on an average was * 1,079 per quintal. But after 2007-08 year the average price was $₹ 2,439$ per quintal. That shows, during after the reform period 2007-08, prices of jaggery improved by 150 per cent more and then hovering around that prices.

Mean monthly prices of jaggery was highest during September ( ₹ 1,820) and lowest in April ( ₹ 1,618) with mean monthly prices for 2000-01 to 2014-15 was ₹ 1,594 (Fig. 4). Thus, prices among the months deviating $₹ 200$ on the both sides of the mean.

If we closely observe the Fig. 2 and Fig. 4, the trends were reverse, which shows, as the supply increases the price of commodity decreases taking the demand as constant. Thus, it is following the natural law of Demand.

\section{CONCLUSIONS}

Total Turn-over was more influenced by the price. That is a good indicator for farmers. Total Turn-Over is more volatile than the total quantity handled. The physical performance of AMC is good, but coming to financial aspects; it is positive and highly volatile. Main reason attributed by committee officials was dearth of office staff.

Growth in production was more influenced by growth in productivity in period - I and Period - II. Whereas, instability in production was more influenced by growth in area in period - I and growth in productivity in Period - II. As the supply increases the price of commodity decreases taking the demand as constant. Thus, it is following the natural law of Demand.

\section{REFERENCES}

[1] Agricultural statistics at a glance (2014) available at http://agricoop.nic.in

[2] Kumar, P. Mruthyunjaya and Ramesh Chand (2010) Food security, Research priorities and Resource Allocation in South Asia, Agricultural Economics Research Review, 23(2):209-226

[3] Maheshwarappa BO, Kunnal LB, Patil SM (1998) Economics of production and marketing of sugarcane in Karnataka. The Bihar Journal of Agricultural Marketing 6(2): 238-244.

[4] Naidu M.R, Rao M.K and T.K.V.V.M. Rao (1986) The co-existence of sugar industry and the jaggery market -A micro analysis, Cooperative Sugar, 18(2): $87 \& 88$

[5] Nerkar Y S (2004) Present scenario and thrust area for making sugarcane and sugar productivity in India. Financing Agriculture Oct-Dec:29
[6] Rao, I.V.Y.Rama, Vasudev, N. and GSK Babu (2011) Impact of WTO on sugarcane performance in Andhra Pradesh, Cooperative Sugar 42(7):37-40

[7] Statistics (2011), Indian Sugar, LXI (7):63-79

[8] Statistics (2014), Indian Sugar, LXIV (7):65-83

[9] Sugar statistics (2014), Cooperative sugars, 41(12): $57-91$

Table.1: Physical Indicators of AMC

\begin{tabular}{|c|c|c|}
\hline Years & $\begin{array}{c}\text { Total Turnover } \\
\text { (Crores) }\end{array}$ & $\begin{array}{c}\text { Total Quanity } \\
\text { (Tonnes) }\end{array}$ \\
\hline $\mathbf{2 0 0 3 - 0 4}$ & 46.5 & 50587.0 \\
\hline $\mathbf{2 0 0 4 - 0 5}$ & 110.3 & 85023.0 \\
\hline $\mathbf{2 0 0 5 - 0 6}$ & 80.5 & 58232.0 \\
\hline $\mathbf{2 0 0 6 - 0 7}$ & 83.9 & 70420.0 \\
\hline $\mathbf{2 0 0 7 - 0 8}$ & 58.8 & 57708.0 \\
\hline $\mathbf{2 0 0 8 - 0 9}$ & 84.4 & 47876.0 \\
\hline $\mathbf{2 0 0 9 - 1 0}$ & 115.5 & 41119.0 \\
\hline $\mathbf{2 0 1 0 - 1 1}$ & 132.3 & 54084.0 \\
\hline $\mathbf{2 0 1 1 - 1 2}$ & 182.8 & 81796.0 \\
\hline $\mathbf{2 0 1 2 - 1 3}$ & 152.1 & 58869.0 \\
\hline Total & $\mathbf{1 0 4 7 . 1}$ & $\mathbf{6 0 5 7 1 4 . 0}$ \\
\hline Average & $\mathbf{1 0 4 . 7}$ & $\mathbf{6 0 4 1 3 . 5}$ \\
\hline S.D & $\mathbf{4 2 . 4 0}$ & $\mathbf{1 3 5 8 6 . 8 2}$ \\
\hline CGR & $\mathbf{1 1 . 5 3}$ & $\mathbf{- 0 . 6 5}$ \\
\hline C.V & $\mathbf{4 0 . 5 0}$ & $\mathbf{2 2 . 4 9}$ \\
\hline
\end{tabular}

Table.2: Financial Indicators of AMC

\begin{tabular}{|c|c|c|c|}
\hline Years & $\begin{array}{c}\text { Income } \\
\text { (Lakhs) }\end{array}$ & $\begin{array}{c}\text { Expenditure } \\
\text { (Lakhs) }\end{array}$ & $\begin{array}{c}\text { Net income } \\
\text { (Lakhs) }\end{array}$ \\
\hline $\mathbf{2 0 0 3 - 0 4}$ & 138.7 & 118.2 & 20.5 \\
\hline $\mathbf{2 0 0 4 - 0 5}$ & 138.7 & 118.2 & 20.5 \\
\hline $\mathbf{2 0 0 5 - 0 6}$ & 154.6 & 138.1 & 16.5 \\
\hline $\mathbf{2 0 0 6 - 0 7}$ & 148.9 & 147.7 & 1.2 \\
\hline $\mathbf{2 0 0 7 - 0 8}$ & 162.9 & 167.9 & -5.0 \\
\hline $\mathbf{2 0 0 8 - 0 9}$ & 166.5 & 188.8 & -22.3 \\
\hline $\mathbf{2 0 0 9 - 1 0}$ & 243.9 & 180.9 & 63.0 \\
\hline $\mathbf{2 0 1 0 - 1 1}$ & 199.1 & 223.5 & -24.4 \\
\hline $\mathbf{2 0 1 1 - 1 2}$ & 234.4 & 293.1 & -58.7 \\
\hline $\mathbf{2 0 1 2 - 1 3}$ & 355.3 & 334.2 & 21.2 \\
\hline Total & $\mathbf{1 9 4 3 . 0}$ & $\mathbf{1 9 1 0 . 5}$ & $\mathbf{3 2 . 5}$ \\
\hline Average & $\mathbf{1 9 4 . 3}$ & $\mathbf{1 9 1 . 1}$ & $\mathbf{3 . 2}$ \\
\hline S.D & $\mathbf{6 7 . 9 8}$ & $\mathbf{7 2 . 9 5}$ & $\mathbf{3 3 . 3 1}$ \\
\hline CGR & $\mathbf{9 . 4 5}$ & $\mathbf{1 2 . 1 0}$ & $\mathbf{8 . 2 1}$ \\
\hline C.V & $\mathbf{3 4 . 9 9}$ & $\mathbf{3 8 . 1 8}$ & $\mathbf{1 0 2 5 . 2 6}$ \\
\hline
\end{tabular}


Table.3: Compound Growth Rate (\%) and Coefficient of Variation (\%) of Sugarcane in Visakhapatnam District

\begin{tabular}{|c|c|c|c|c|c|c|}
\hline \multirow{2}{*}{ Particulars } & \multicolumn{2}{|c|}{ Area } & \multicolumn{2}{c|}{ Production } & \multicolumn{2}{c|}{ Productivity } \\
\cline { 2 - 7 } & Period-I & Period-II & Period-I & Period-II & Period-I & Period-II \\
\hline CGR & -1.85 & -0.83 & 2.25 & 4.23 & 4.17 & 5.10 \\
\hline CV & 25.67 & 4.06 & 16.27 & 18.35 & 24.80 & 19.51 \\
\hline
\end{tabular}

Fig.1: Year wise arrivals of jaggery in anakapalle regulated market (2000-01 to 2014-15)

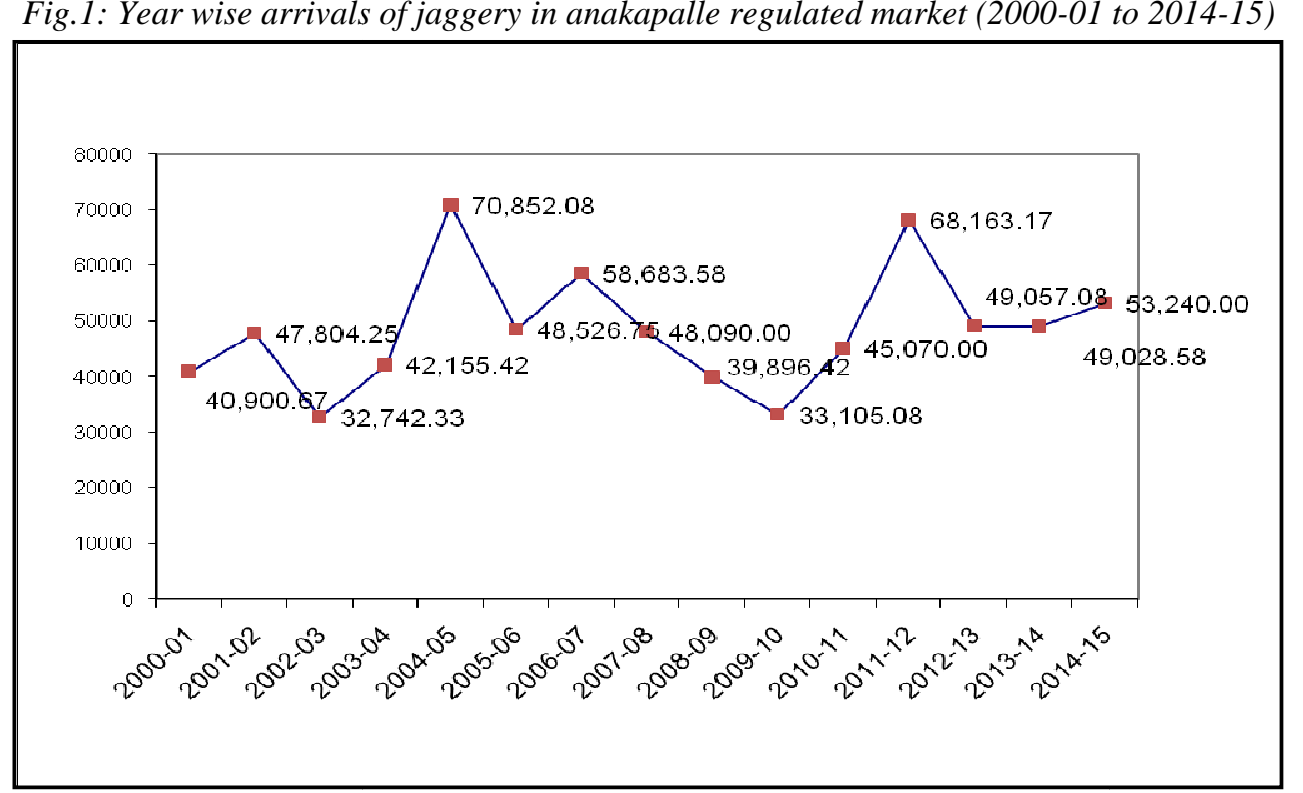

Fig.2: Month wise arrivals of jaggery in anakapalle regulated market (2000-01 to 2014-15)

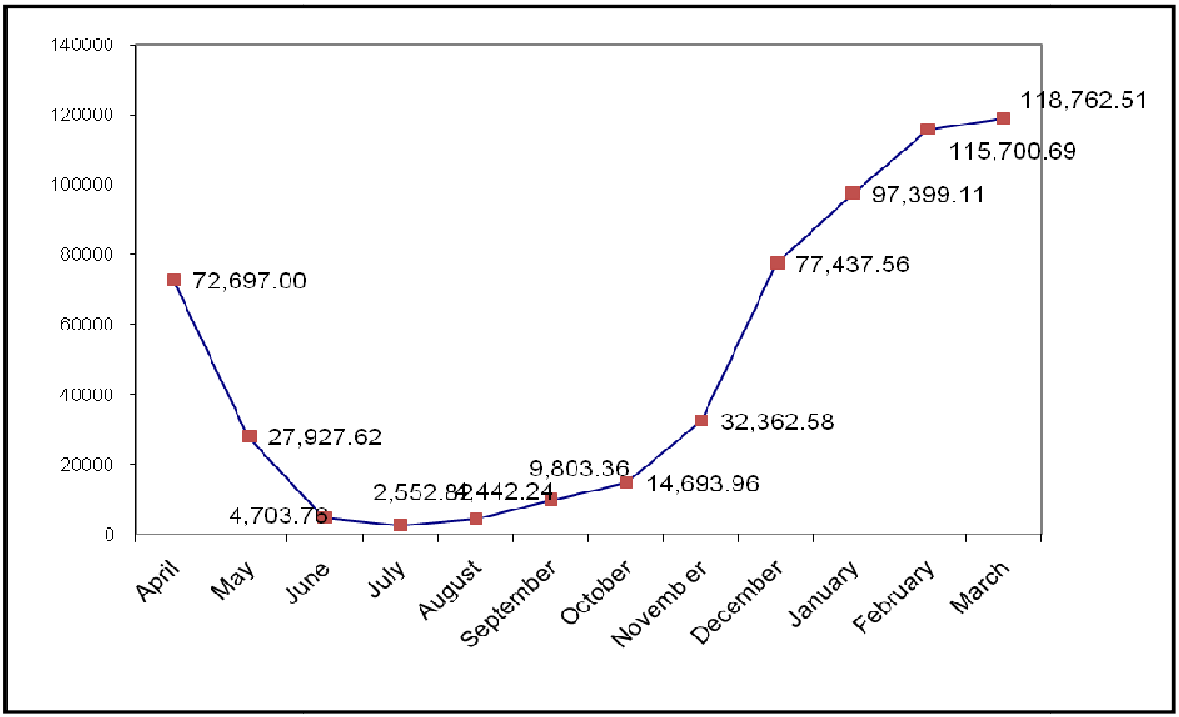


Fig.3: Year wise prices of jaggery in anakapalle regulated market (2000-01 to 2014-15)

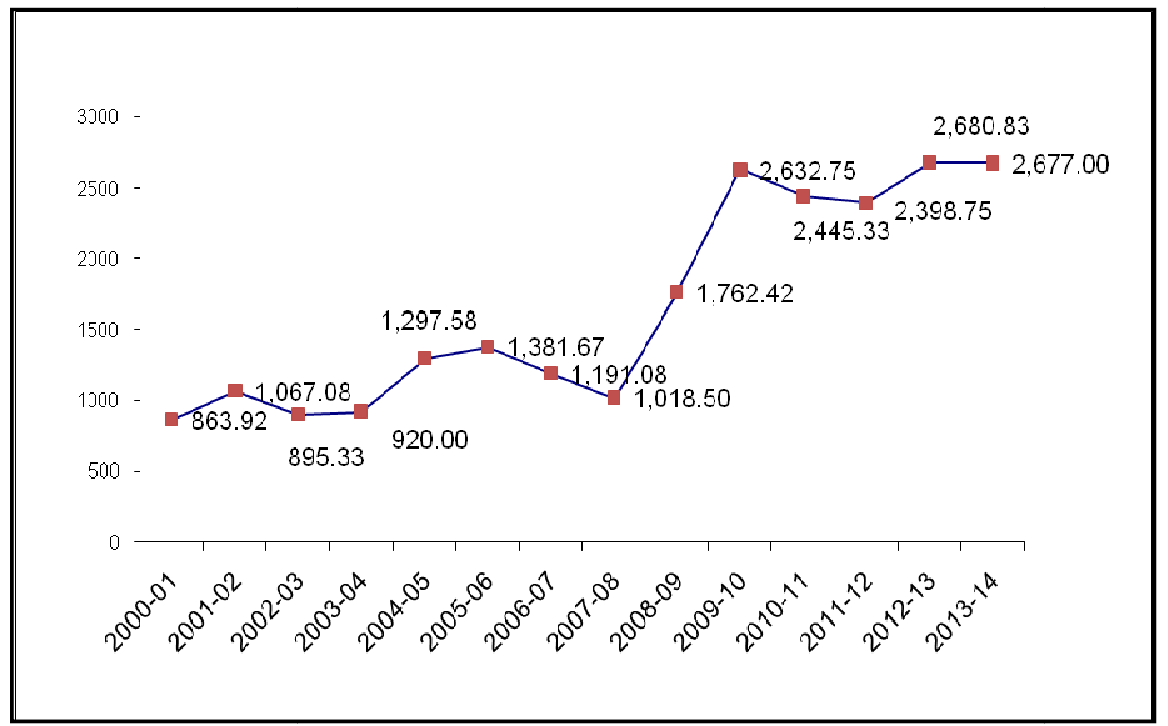

Fig.4: Month wise prices of jaggery in anakapalle regulated market (2000-01 to 2014-15)

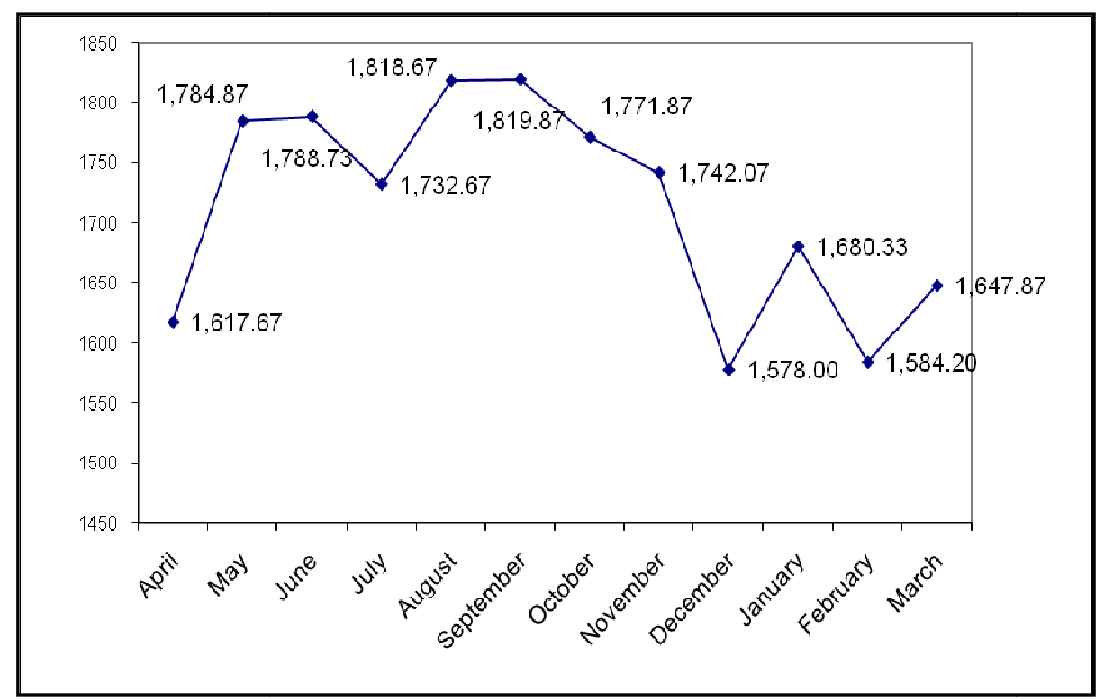

